\title{
PEMIKIRAN IKHWANUS SHAFA TENTANG PENDIDIKAN DAN RELEVANSINYA DENGAN PENDIDIKAN DI INDONESIA
}

\author{
Budi Agus Sumantri*
}

\begin{abstract}
Abstrak: Ilmu pendidikan pada dasarnya merupakan rangkaian pengalaman panjang kegiatan manusia sepanjang pendidikan sejarah yang disusun secara sistematis sehingga mudah dipahami, diuji, diterapkan, dan dikembangkan dari generasi ke genarasi. Sehingga konsep dan teori pendidikan yang ada sekarang atau masa depan, dikembangkan kembali di masa depan oleh para ahli. Hal ini pada intinya merupakan upaya untuk terus berpikir, mengalami dan membangun budaya yang telah dikembangkan oleh generasi sebelumnya. Untuk itu mengkaji pemikiran filsuf dan ulama yang ahli dibidang pendidikan yang sampai sekarang tetap merupakan kegiatan yang relevan dengan dunia global/modern. Tulisan ini berusaha untuk mengidentifikasi secara konkrit tentang siapa dan bagaimana perumusan pemikiran pendidikan Ikwanus Shafa dan relevansinya terhadap Era global/modern.
\end{abstract}

Kata Kunci: Ikhwanus Shafa, pendidikan, relevansi, dunia global/modern.

\section{Pendahuluan}

- Welah kita ketahui bersama bahwa banyak berkembang filsafat pendidikan Islam sejak Islam lahir di muka bumi ini. Para L filsuf dengan kecakapan mereka dalam berfilsafat, menemukan konsep-konsep pendidikan baru yang di zaman selanjutnya, konsep-konsep pendidikan itu menjadi landasan dasar

* Program Pascasarjana Prodi Pendidikan Agama Islam Fakultas Tarbiyah dan Keguruan Universitas Islam Negeri Sunan Kalijaga Yogyakarta. Jalan Laksada Adisucipto, Caturtunggal, Kec Depok, Kabupaten Seleman, Daerah Istimewa Yogyakarta, 089673866892, budisumanti0045@gmail.com. 
pengembangan pendidikan. Hal ini dikarenakan pendidikan menjadi sarana untuk memperbaiki moral bangsa.

Salah satu pandangan tentang konsep pendidikan adalah konsep pendidikan menurut Ikhwan al-Shafa, hal ini menjadi penting karena Ikhwan al-Shafa menitik beratkan tujuan pendidikan itu untuk pengenalan diri. Selain itu, Ikhwan al-Shafa juga mengedepankan kepentingan sosial di atas kepentingan pribadi. Hal ini akan menimbulkan nilai-nilai baik pada peserta didik, antara lain memberi. Jika nilai ini terus dikembangkan, maka seorang peserta didik akan menjadi orang yang bermanfaat bagi orang lain, yang kedatangannya dinantikan, dan tentu perbaikan-perbaikan sosial yang dilakukan di masyarakat akan mudah dicapai. Untuk lebih jelasnya, filsafat dan konsep pendidikan Ikhwan al-Shafa akan dibahas dalam makalah ini.

\section{Biografi Ikwan Al-Ashafa}

Ikhwan al-ashafa adalah perkumpulan para mujtahidin dalam bidang filsafat yang banyak memfokuskan perhatiannya pada bidang dakwah dan pendidikan. (Nata, 1997: 181). Sesuai dengan namanya, ikhwan al-ashafa berarti "persaudaraan yang sucidan bersih", maka asas utama perkumpulan ini adalah perasudaraan yang dilakukan secara tulus ikhlas, kesetiakawanan yang suci murni, serta saling menasehati antara sesama anggota dalam menuju ridha Ilahi. (Nizar, 2002: 96-97). Perkumpulan ini lahir pada abad ke-10 $\mathrm{M}$ di kota Basrah, pada masa pemerintahan al-Mansyur, khalifah kedua Bani Abbas. Dari Basrah, Ikhwan al-Shafa terus menyebar dan berkembang ke berbagai daerah seperti Iran dan Kuwait. Dalam perkembangannya, perkumpulan ini menggunakan cara yang halus denagn mengutus beberapa orang-orang yang dianggap dapat bekerjasama, terutama dari kalangan pemuada. (Nizar, 2002: 96)

Secara umum, kemunculan Ikhwan as-Shafa dilatar belakangi oleh keprihatinan terhadap pelaksanaan ajaran Islam yang telah tercemar oleh ajaraan-ajaran dari luar Islam, serta untuk membangkitkan kembali rasa cinta pada ilmu pengetahuan di 
kalangan umat Islam. Kelompok ini sangat merahasiakan namanama anggotanya. Mereka bekerja dan bergerak secara rahasia, disebabkan kekawatiran akan ditindak penguasa waktu itu yang cenderung menindas gerakan-gerakan pemikiran yang timbul. Kondisi ini yang antara lain ynag menyebabkan Ikhwan as-Shafa memiliki anggota yang terbatas. Mereka sangat selektif dalam menerima anggota baru degan melihat berbagai aspek. Di antara syarat tersebut adalah memiliki ilmu pengetahuan yang luas, loyalitas yang tinggi, kesungguhan, dan berakhlak mulia. (Nizar, 2002: 96-97)

Menurut Maragustam, bahwa diantara angota-anggotanya yang dapat diketahui nama-nama mereka adalah sebanyak lima orang, yaitu: (Maragustam, 2014: 161).

1. Abu Sulaiman Muhammad Ibnu Masyar al-Basti dikenal dengan nama al-Maqdisy

2. Abu al-Hasan Ali Ibnu Harun ad-Zanjany

3. Abu Ahmad al-Mahrajani

4. Al-Qufy

5. Zaid Ibnu Rifa'ah (Madjidi, 1999).

Aktivitas Ikwan as-Shafa difokuskan untuk mempelajari filsafat, baik fisafat Yunani, Persia, dan lain sebagainya yang kemudian dipadukan dengan ajaran Islam, sehingga menjadi suatu ikhtisar dan mazhab filsafat sendiri. Dari hasil pembahasanya, Ikhwan as-Shafa menyusun sebuah buku yang terdiri dari sejumlah risalah yang berjudul "Rasail Ikhwan al-Shafa wa al-Kullah al-Wafa". Kitab ini terdiri atas empat jilid yang berisikan ikhtisar tentang pengetahuan yang ada ketika itu yang mencakup semua objek studi manusia. (Nizar, 2002: 97). Ditilik dari segi isi, rasail tersebut dapat diklasifikasikan kepada empat bidang yang berjumlah 52 rasail di dalamnya yaitu: (Nasution, 2002: 46)

1. 14 risalah tentang mematika, yang mencakup geometri, astronomi, musik, geografi, teori dan praktek seni, moral dan logika.

2. 17 risalah tentang fisika dan ilmu alam, meliputi geneologi, minerologi, botani, hidup dan matinya alam, senang dan 
sakitnya alam, keterbatasan manusia, dan kemampuan kesadaran.

3. 10 risalah tentang jiwa, meliputi metafisika mazhab pytagoreanisme dan kebnagkitan alam.

4. 11 risalah tentang ilmu-ilmu ketuhanan, mencakup kepercayaan, keyakinan, hubungan alam dengan Tuhan, keyakinan Ikhwan al-Shafa, kenabian dan keadaannya, tindakan rohani, bentuk kontitusi politik, kekuasaan Tuhan, magic dan jimat.

Frederich Dieterici sebagai mana yang dikutip Nakosteen menunjukan dalam refrensinya bahwa pemahaman terhadap isi kitab Rasail Ikhwan as-Shafa merupakan persyaratan utama bagi para cendikiawannya untuk menguasai pengetahuan tentang asas-asas pendidikan. Kitab tersebut merupakan usaha intensif pertama yang dilakukan Ikhwan as-Shafa dalam mengabungkan semua ilmu dengan ajaran Islam. Pada bab XIV, kitab tersebut membicarakan tentang filologi dan psikologi yang sangat penting bagi para mahasiswa. (Nizar, 2002: 97).

Dari data yang ada, dapat dilihat bahwa latar belakang penulisan Risalah Ikhwan as-Shafa bersal dari perasaan tidak puas terhadap pendidikan dan gaya hidup umat Islam ketika itu. Karenanya, program rekonstruksi Ikhwan as-Safa diarahkan pada dua aspek, yaitu: (Nizar, 2002: 97).

1. Memperkenalkan ide-ide pemilihan dari semua sumber yang ada terhadap segala sesuatu dan berguna memilih maksud dari semua pengetahuan yang diperoleh.

2. Merancang manfaat atas semua pengetahuan, baik untuk dirinya sendiri, lingkungan, dan alam semesta, sehingga setiap individu akan mempunyai kesempatan untuk berbuat sesuai dengan pengetahuan dalam rangka meraih kebahagian di dunia dan akhirat.

Organisasi ini antara lain mengajarkan tentang dasar-dasar agama Islam yang didasarkan pada persaudaraan Islamiyah (Ukhuwwah Islamiyyah), yaitu suatu sikap yang memandang seseorang muslim tidak akan sempurna kecuali ia mencintai 
saudaranya seperti mencintai saudaranya sendiri. Sebagai sebuah organisasi ia memiliki semangat semangat dakwah dan tabligh yang amat militan dan kepedulian yang tinggi terhadap orang lain. Semua anggota perkumpulan ini wajib menjadi guru dan mubaligh terhadap orang lain yang terdapat di masyarakat. Dan disinilah letak relevansinya berbicara Ikhwan al-Shafa dengan pendidikan. (Nata, 1997: 181)

\section{Konsep Pendidikan Ikhwan Al-Shafa}

Menurut Ikhwan as-Shafa, aktivitas pendidikan dimulai sejak sebelum kelahiran. Sebab, kondisi diri bayi dan perkembangannya sudah dipengaruhi oleh keadaan kehamilan dan kesehatan sang ibu yang hamil. Dengan demikian, perhatian pendidikan harus sudah diberikan sejak masa janin dalam rahim. (Ridla, 2002: 164)

Kesadaran kuat Ikhwan as-Shafa terhadap urgensi indera dalam memperoleh pengetahuan dan imperasinya dalam keberadaan manusia, baik dataran empiris-sensual maupun empiris-logis, membawa mereka pada pengapresiasian peran dan fungsi fisikjasmaniah untuk kebahagiaan manusia dan kenormalan hidupnya. Mereka secara khusus menulis tentang masalah ini dalam risalah fashl al-jismaniyah (bab pengaturan fisik-jasmaniah). Di sini, mereka menekankan perlunya memperhatikan fisik-jasmaniah, memeliharanya dan mengaturnya dengan seksama agar jangan sampai tidak terurus kebutuhan makan dan minumnya. (Ridla, 2002: 167-168)

\section{Konsep tujuan pendidikan menurut Ikhwan al-Shafa}

Ikhwan al-Shafa mengawali pengkajiannya dengan merumuskan tujuan-tujuan individual dan sosial yang ingin di realisasikan melalui aktivitas pendidikan. Secara nyata mereka memberi porsi lebih terhadap tujuan sosial dibandingkan dengan tujuan individual. (Ridla, 2002: 151). Ikhwan al-Shafa mengkonsepsikan ilmu bukan sebagai sesuatu yang mengandung tujuan dalam dirinya sendiri. Ilmu itu harus difungsikan untuk pelayanan tujuan luhur kependidikan, yaitu pegenalan diri. Menurutnya tujuan para filosof dan pakar mempelajari 
ilmu-ilmu pasti dan mengajarkannya kepada kepada murid adalah al-suluk (pembentukan karakter diri) dan penitian ke arah penguasaan ilmu-ilmu kealaman (Fisika), sedangkan tujuan mereka mempelajari ilmu-ilmu kealaman adalah pendakian menuju penguasaan ilmuilmu keTuhanan (Teologis) yang menjadi puncak tujuan para filosof dan ilmuwan bijak, dan muara muara dari ragam pengetahuan tentang hakikat. (Ridla, 2002: 152).

Mengingat tahapan awal pemahaman ilmu-ilmu ketuhanan adalah pengenalan akan subtansi jiwa, pengkajian perihal awal kejadian sebelum bersatu dengan jasad, penelaahan tentang muara akhirnya setelah berpisah dengan jasad dan tentang perihal pahala yang akan diterima orang-orang yang baik di akhirat, dan hal-hal lain, mengingat juga manusia sangat dituntut untuk mengenali (ma'rifat) terhadap Tuhannya, sementara hal ini hanya bisa dirahi bila ia telah mampu mengenali dirinya sendiri, seperti yang difirmankan Allah, "Dan tidaklah ada orang yang membenci agam Ibrahim, kecuali orang yang tidak mengenali dirinya sendiri” (jabl alnafs), dan sepertia apa yang diungkapkan, " Barang siapa mengenal dirinya sendiri, maka ia akan mampu mengenali (ma'rifat) Tuhanya. Maka setiap orang yang berakal dituntut untuk mencari mempelajari ilmu tentang jiwa, pengetahuan tentang subtansinya dan cara penyuciannya, Allah SWT Berfirman," Demi jiwa dan apa yang dia telah menyempurnakannya. Dia tekah membekali jiwa keburukan dan ketakwaannya. Sungguh beruntung orang yang mau membersihkan jiwa, dan sungguh merugi orang yang mengotorinya. (Ridla, 2002: 152).

Dari uraian di atas dapat ditarik kesimpulan bahwa tujuan utama pendidikan menurut ikhwanus Shafa adalah pengenalan diri, pembentukan karakter diri dan mengetahui ma'rifat ke'Tuhanan. Yang mana untuk sampai pada derajat itu kita diharuskan untuk mengenali diri sendiri, karena mengenal diri sendiri merupakan salah satu cara agar seseorang dapat mengenali/mengetahui ma'rifat Allah SWT.

Konsep manusia dalam pandangan Ikhwan as-Shafa 
Kelompok ikhwan as-Shafa mempunyai pandangan dualistik tentang konsep dasar manusia. Mereka membuat formulasi konseptual atas pandangan moral-etik tentang manusia. Menurut Ikhwan, sekiranya manusia itu tersusun dari unsur fisik-biologis dan unsur jiwa-rohaniah, maka sejatinya kedua unsur ini memiliki perbedaan sifat dan berlawanan kondisinya, namun memiliki kesamaan dalam tindakan dan sifat aksidentalnya. Karena unsur fisik-biologisnya, manusia berkecenderungan untuk kekal di dunia dan hidup selama-lamanya. Sedangkan karena unsur jiwarohaniahnya, manusia berkecenderungan untuk meraih akhirat dann keselamatan di sana. Dengan demikian kondisi kehidupan manusia diwarnai oleh dualitas berlawanan, seperti hidup dan mati, pengetahuan dan kebodohan, ingat dan lupa, serta susah dan senang. Ikhwan as-Shafa secara halus menguatkan pengakuan mereka tentang ragam potensi psikomotorik, kognitif, dan afektif pada masing-masing individu. (Ridla, 2002: 153-154).

Menurut ikhwan as-Shafa bahwa perumpamaan orang yang belum dididik dengan ilmu akidah, ibarat kertas yang masih putih bersih, belum ternoda apa pun juga. Apabila kertas ini ditulis sesuatu, maka kertas tersebut telah memiliki bekas yang tidak akan mudah untuk dihilangakan. Organisasi ini memandang pendidikan dengan pandangan yang bersifat rasional dan empirik, atau perpaduan antara pandangan yang bersifat intelektual dan faktual. Mereka memandang ilmu sebagai gambaran dari sesuatu yang dapat diketahui di alam ini. Dengan kata lain ilmu yang diperoleh manusia itu terjadi karena mendapat bahan-bahan informasi yang dikirim oleh panca indra. (Nata, 1997: 182)

Ketika lahir, jiwa manusia tidak memiliki pengetahuan sedikitpun. Proses memperoleh pengetahuan digambarkan Ikwan as-Shafa secara dramatis dilakukan melalui pelimpahan (al-faidh). Proses pelimpahan tersebut bermula dari jiwa universal (al-nafs alkulliyah) kepada jiwa manusia, setelah terlebih dahulu melalui proses emansi. Pada mulanya, jiwa manusia kosong. Setelah indra berfungsi, secara berproses manusia mulai menerima rangsangan dari alam seitarnya. Semua rangsangan indrawi ini melimpah 
kedalam jiwa. Proses ini pertama sekali memasuki daya pikir (alquwwah al-mufakkirat), kemudian diolah untuk selanjutnya disimpan di dalam re-koleksi atau daya simpan (al-quwwah al-hafizhat) sehingga akhirnya sampai pada daya penuturan (al-qumwah al-nathiqat) untuk kemudian siap direproduksi. (Nizar, 2002: 99).

\section{Konsep pendidik menurut Ikhwan as-Shafa}

Ikwan as-Shafa menempatakan pendidik (guru) pada posisi strategis dan inti dalam kegiatan pendidikan. Mereka mempersyaratkan kecerdasan, kedewasaan, kelurusan moral, ketulusan hati, kejernihan pikir, etos keilmuan dan tidak fanatik buta pada diri pendidik. Ikwan as-Shafa menganggap bahwa mendidik sama dengan menjalankan fungsi "bapak" kedua, karena pendidikan atau guru merupakan bapak bagi dirimu, pemelihara pertumbuhan dan perkembangan jiwa, sebagaimana halnya kedua orang tuamu adalah pembentuk rupa fisik-biologismu, maka guru adalah pembentuk rupa mental-rohaniahmu. Sebab guru telah menyuapi jiwamu ke jalan keselamatan dan keabadian, seperti apa yang dilakukan oleh kedua ornag tuamu yang memnyebabkan tubuhmu lahir ke dunia, mengasuhmu dan mengajarimu mencari nafkah hidup di dunia fana ini. (Ridla, 2002: 169).

\section{Konsep ilmu pengetahuan menurut Ikwan as-Shafa}

Menurut ikwan as-Shafa ilmu pengetahuan itu dapat dicapai melalui dua cara: (Nata, 1997: 182).

1. Dengan cara mempergunakan panca indra terhadap obyek alam semesta yang bersifat empirik. Ilmu model ini berkaitan dengan tempat dan waktu.

2. Dengan cara mempergunakan informasi atau berita yang disampaikan oleh orang lain. Ilmu yang dicapai dengan cara kedua ini hanya dapat dicapai oleh manusia, dan tidak dapat dicapai oleh binatang. Dengan cara yang kedua ini pula manusia dapat memperoleh pengetahuan tentang hal yang ghaib. 
Selain itu ikwan as-Shafa menyampaikan tentang ilmu yang dapat dicapai melalui bacaan dan tulisan. Dengan cara ini manusia dapat memahami kalimat, bahasa, dan ungkapan-ungkapan yang ditangkap melalui pemikiran. Pada bagian lain Ikwan as-Shafa berpendapat bahwa pada dasarnya semua ilmu itu harus diusahakan (muktasabah), bukan dengan cara pemberian tanpa usaha. Ilmu yang demikian didapat dengan mempergunakan panca indra. (Nata, 1997: 182).

Ikwan as-Shafa juga berpendapat bahwa untuk mendapatkan ilmu tersebut adalah dengan cara membiasakan berpegang pada pembiasaan dan perenungan. Dalam hubungan ini ia mengatakan "Hendaknya diketahui pembiasaan dan latihan itu harus dilakukan secara kontinyu, dan dari pembiasaan ini akan dhasilkan akhlak yang kokoh, sebagaimana hal itu terjadi dalam bidang ilmu. Pembiasaan itu juga berhubugan dengan mudzakarah yang dapat memperkuat daya ingatan dan kedalaman ilmu. (Nata, 1997: 184).

Ikwan as-Shafa membagi sumber pengetahuan ke dalam empat dimensi:

1. Kitab suci yang diturunkan, semisal taurat, injil dan Al-Quran

2. Kitab-kitab yang disusun oleh para bukama' (orang-orang bijak) dan filosofis, baik berupa matematika, fisika-kealaman, sastra dan Filsafat

3. Alam, yakni bentuk empiris (phenoumenon) segala yang sesuatu sebagai mana adanya

4. Perenungan alam semesta dan tata aturan kosmiknya, atau sering disebut subtansi noumenon, ragam dan macamnya serta kaitan fungsioanalnya dengan kenyataan empiris (penoumenon).

Ada keistimewaan lain yang dimiliki ikhwan as-Shafa, sebagai suatu keistimewaan yang paling menonjol. Mereka menolak fanatisme, dan berpegang pada kebebasan berpikir kritis untuk mencari kebenarann. Mereka menyeru kepada para pengikutnya agar tidak mengabaikan satu disiplin keilmuan pun, tidak bersikap antipati terhadap satu kitab pun, atau bersikap fanatik buta terhadap madzhab tertentu. (Ridla, 200: 148) 
Melalui empat keistimewaan, pertama, aplikasi keilmuan atas problema soaial melalui sistem pendidikan yang efektif dan beroreantasi pada rekonstruksi keseimbangan ranah intelektual dan moral, dan pembebasan potensi nalar masyarakat luas. Kedua, paradigam ta'limiy (pengajaran) dalam agenda politiknya. Ketiga, diverisifikasi sumber-sumber pengetahuan. Dan keempat, penolakan panatisme buta, (peneguhan) paham kebebasan dan apresiasi pluralitas pemikiran sebagai hal produktif bagi dinamika intelektual dan sosial, kelompok ikhwan as-Shafa mampu memerankan fungsi strategis dalam sejarah gerakan pemikiran Islam dan memberikan pengaruh positif yang nyata terhadapnya. (Ridla, 2002:150).

\section{Ciri-ciri Dunia Modern/Global}

Pendidikan pada umumnya dan pendidikan Islam khususnya mempunyai perannan yang sama bagi kehidupan umat manusia agar manusia dapat mengarungi kehidupan di dunia dan memperoleh kemenangan-kemenangan yang hakiki, yaitu memperoleh kebaghagian dan kenikmatan hidup tidak hanya di dunia yang fana ini tetapi juga pada kehidupan akhirat yang kekal. (Abdullah, dkk, 2004: 25-26).

Hidup di dunia tampaknya telah sampai pada era global/ modern yaitu era dimana kehidupan telah mendunia ditandai dengan, tranportasi ke segala arah dengan begitu mudah, komunikasi dengan cepat, dan perdagangan bebas pasti terjadi. Hal itu berdampak pada perubahan dalam bermasyarakat, berekonomi, dan berpolitik pada setiap negara, sehingga menimbulkan berbagai permasalahan menyangkut pada pendidikan umumnya dan pendidikan Islam pada khususnya. (Abdullah, dkk, 2004: 26).

Menurut Daniel Bell, sebagaimana dikutip oleh Mochtar Buchori, bahwadi era global saat ini masyarakat di hadapkan kepada lima kecenderungan yang membawa dapmapak bagi kehidupan yang amat luas, kelima kecenderungan tersebut sebagai berikut: (Nata, 2003: 69)

1. Kecenderungan untuk berintegrasi dalam kehidupan ekonomi, yang mana akan berimlikasi pada dunia pendidikan. 
2. Kecenderungan untuk berpecah belah (fragmatasi) dalam kehidupan politik. Fragmatasi in terjadi karena semakain terbukanya kebebasan untuk menyatakan hak-hak seseorang, menuntut perlakuanyang lebih adil dan demokratis, peningkatan dan pemerataan kesejahteraan, baik dalm bidang ekonomi, kesehatan, pendidikan, dan sebagainya.

3. Kecenderungan interdependesi (kesaling tergantunagan) antara satu negara dengan negara lain.

4. Kecenderungan semakin meningkatnya kemajuan dalam bidang ilmu pengetahuan dan teknologi yang selanjutnya mengubah secara radikal situasi pasar kerja.

5. Kecenderungan semakin tergesernya kebudayaan dan tradisi masa lalu oleh kebudayaan dan tradisi baru yang selanjutnya menimbulkan apa yang kita sebut dengan new colonization in culture (penjajahan baru dalam bidang kebudayaan). Yaitu perubahn pola pikir, sikap, perilaku dalam berpakaian, dll.

\section{Relevansi Pemikiran Pendidikan Ikwan As-Shafa Dengan Pendidikan Di Indonesia.}

Ada beberapa implikasi dari pemikiran ikwanus Shafa di era grlobal, diantaranya sebagai konsekuensin formulasi realisasi komplemeter dari konsepsi Ikhwanus Shafa tentang manusia, pengetahuan, ilmu/program kurikuler dan belajar, maka mereka membangun teori pendidikan yang komperehensif, sempurna dan gradual. (Ridla, 200: 164). Adanya kecenderungan merumuskan dasar-dasar fisiologis bagi pengetahuan, pengokohan urgensi indra bagi sistematisasi cerapan manusia terhadap dunia luar, pembentukan persepsi-persepsi, dan vitaliitas kesehatan fisikjasmaniah bagi kehidupan manusia, baik individual maupun kolektif, tidak memalingkan Ikhwan dari hakikat tujuan utama pendidikan yaitu moral.

Totalitas pendidikan merupakan aktivitas moral, mereka menyebutnya dengan al-siyasah al-nafsiyyah_agar moralmu menjadi baik, kebiasanmu menjadi positif dan tindakanmu menjadi lurus: mau menyampaikan amanat kepada yang berhak, pandai 
mngendalikan diri, menghormati hak orang lain, bersikap baik kepada tetangga, bersikap tulus kepada sesama, penuh cinta-kasih, tidak rakus, tidak suka berkeluh kesah, bersikap empatik, berbuat tanpa pamrih, karena bila punya pamrih untuk dibalas, maka tidak lagi bernilai kebaikan, atau punya pamrih disanjung, maka ini adalah ke-nifaq-an dan tidak pantas bagi orang semacam itu berada dibarisan mkhluk ruhaniah yang mulia. (Ridla, 2002: 153-154).

Dengan demikian Ikwanus Shafa secara halus mencuatkan pengakuan mereka tentang ragam potensi psikomotorik, kognitif, dan afektif pada masing-masing individu. (Ridla, 2002: 156). Hal ini tentu saja sangat relevan dengan pendidikan yang ada pada zaman sekarang, yang mana dalam proses pembelajaran ketiga ranah diatas sangat ditekankan dalam setiap aspek yang diajarkan di dalam kelas, tidak terkecuali penilaian dan evaluasi yang mencakup ketiga ranah tersebut.

Menurut Busyairi Madjidi, didalam buku Filsafat Pendidikan Islam karangan Maragustam, menjelaskan bahwa beberapa contoh pokok pikiran mereka mengenai pendidikan dan pengajaran masih relevan dengan pendidikan modern sekarang. Diantaranya ialah: (Maragusta, 2014: 164).

1. Mengenai tujuan pendidikan mereka melihat bahwa tujuan pendidikan haruslah dikaitkan dengan keagamaan. Tiap ilmu, kata mereka merupakan malapetaka bagi pemiliknya bila ilmu itu tidak ditujukan kepada keridhoan Allah dan kepada keakhiratan. Tujuan pendidikan tersebut menurut penulis masih relevan dengan tujuan pendidikan di saat ini, sebagaimana yang telah di sebutkan dalam UU sisdiknas pendidikan yang berbunyi bahwa ; Tujuan Pendidikan Nasional dalam UU No. 20 tahun 2003 Pasal 2 : "Untuk berkembangnya potensi peserta didik agar menjadi manusia yang beriman dan bertakwa kepada Tuhan Yang Maha Esa, berakhlak mulia, sehat, berilmu, cakap, kreatif, mandiri, dan menjadi warga negara yang demokratis serta bertanggung jawab". (Undang-Undang RI No 20 Tahun 2003, 17). Dengan begitu, Seharusnya menjadi sesuatu yang wajib bagi mereka (yang mengutamakan pendidikan untuk tujuan duniawi saja) 
untuk membatasi pendidikan umum mereka dengan tujuan mendapat ridho allah dan akhirat. Karena dengan begitu, ilmu yang mereka dapatkan akan mengangkat derajat mereka (dari segi material maupun inmaterial).

2. Mengenai kurikulum pendidikan tingkat akademis mereka berpendapat agar dalam kurikulum tersebut mencakup logika, filsafat, ilmu jiwa, pengkajian kitab agama samawi, kenabian, ilmu syarat dan ilmu pasti. Namun yang lebih perhatian adalah ilmu keagamaan yang merupakan tujuan akhir dan pendidikan. (Abudin Nata 1997, 184). Dengan demikian kurikulum yang dirumuskan Ikhwanus Shafa ini sangat relevan dengan kurikulum pendidikan sekarang, sesuai dengan UU No. 20 tahun 37 ayat 1, yang berbunyi "kurikulum pendidikan dasar dan menengah wajib memuat pendidikan agama, pendidikan kewarganegaraan, bahasa, matematika, ilmu pengetahuan alam, ilmu pengetahuan sosial, seni, dan budaya, pendidikan jasmani, dan olah raga, keterampilan/kejujuran dan muatan local. Sedangkan pada ayat 2 pasal 37 berbunyi kurikulum pendidikan tinggi wajib memuat, pendidikan agama, pendidikan kewarganegaraan, dan bahasa. (Undang-Undang RI No 20 Tahun 2003).

3. Mengenai metode pengajaran dia mengemukakan prinsip: “ mengajar dari hal yang konkrit kepada abstrak". Berkata Ikhwanus Shafa dalam Rasailnya:'Seharusnya orang yang akan mempelajari dasar-dasar segala sesuatu yang ada (Maujudat), Karena pengenalan hal-hal yang konkrit lebih banyak menolong bagi pelajar-pelajar pemula untuk memahami. Metode pemberian contoh-contoh menurut mereka sangat perlu dalam pengajaran, anak-anak akan mudah menerima pelajaranpelajaran. (Maragustam 2014,164).

Metode pengajaran Ikhwan masih terpakai dan terealisasikan pada masa ini ialah misalnya pada proses pengajaran seorang guru/ dosen yang memberikan contoh-contoh, atau demonstrasi dan pengenalan terhadap objek-objek pengetahuan dalam 
membantu peserta didik dalam memahami materi yang dipelajari.

4. Standar kompetensi guru Menurut Ikwanus Sahafa, berguru dalam menuntut ilmu sangat penting dalam pandangan pendidik-pendidikan Islam. Karena menurut Ikhwanus Shafa pengetahuan itu mempunyai syarat-syarat. Syarat-syarat itu dapat diketahui dalam batas kesanggupan seseorang. Untuk itu di perlukan guru atau pendidik bagi pengajarannya, budi pekertinya, tutur bahasanya, akhlak dan pengetahuannya. Ikhwanus Shafa Menentukan syarat-syarat seorang guru sesuai dengan madzhab mereka. "ketahuilah hai saudara-saudara guru yang cocok bagi saudara adalah guru yag cerdas, baik tabiatnya dan budi pekertinya, jernih batinya, cinta ilmu, mencari kebenaran, tidak fanatik madzhab manapun. Menurut Ikhwanus Shafa yang dikutip Ridha, bahwa pendidik (guru) mempunyai posisi strategis dalam praktik pendidikan untuk itu aliran ini mempersyaratkan guru itu dengan kecerdasan, akhlak baik, hati tulus, tabiat lurus, pkiran jernih, menyukai ilmu, bertugas mencari kebenaran, dan tidak bersifat fanatik terhadap suatu aliran. (Maragustam, 2014: 170).

Demikian pemikiran ikhwanus shafa tentang guru ini masih memiliki relevansi dengan standart kompetensi guru di masa modern, yang mana sudah di atur oleh menteri pendidikan nasional republik indonesia nomor 16 tahun 2007 tentang standar kualifikasi akademik dan kompetensi guru ; bahwa dalam rangka pelaksanaan Pasal 28 ayat (5) PP Nomor 19 Tahun 2005 tentang Standar Nasional Pendidikan, perlu menetapkan Peraturan Menteri Pendidikan Nasional tentang Standar Kualifikasi Akademik dan Kompetensi Guru, dalam Pasal 1 ayat 1 yang berbunyi "Setiap guru wajib memenuhi standar kualifikasi akademik dan kompetensi guru yang berlaku secara nasional".

5. Perbedaan bakat dan individual dan sebab-sebabnya Ikhwanus Shafa berpendapat bahwa anak didik, dapat menerima sesuatu kepandaian bila sesuai dengan pembawaan mereka 
masing-masing. Sementara orang ada yang berbakat pada satu macam kepandaian atau beberapa macam kepandaian. Mereka dengan gampang menerima kepandaian itu sampai mencapai prestasi yang tinggi. Dalam waktu yang singkat sudah dapat diketahui dari pekerjaan mereka, bahwa mereka betul-betul berbakat. Tetapi ada pula orang yang memerlukan dorongan yang besar dan upaya yang keras untuk mengejar satu kepandaian, karna tak sesuai dengan bakat pembawaannya, dan tidak ada bintang yang memberi bekal pada hari kelahiranya lalu gagal. Dalam pandangan itu terapat pula sebagaian orang yang sama sekali tak mempelajari kepandaian, dia kosong dari segala macam kepandaian.

Demikianlah pendapat Ikhwanus Shafa bahwa adanya perbedaan individual, watak dan pembawaan, dapat diterima oleh ilmu pendidikan dan psikologi modern. Akan tetapi bila perbedaan dikaitkan dengan kelahiran dan kehadiran benda-benda langit tertentu, tidak lah sesuai dengan ilmu pengetahuan modern. (Maragustam, 2014: 164-165).

6. Sifat-sifat pengabdi ilmu Ikwanus Shafa melihat kewajiban seseorang belajar ialah, merendahkan diri (tawadduh) kepada siapa dia belajar, hormat dan ta'dzim (hormat) kepadanya dan mengetahui haknya. Kepada guru dinasehatkan agar lembut kepada murid-murid yang lambat memahami pelajaran atau mengahafal pelajaran, tidak rakus dan minta imbalan. Mereka juga menyampaikan tujuh syarat bagi pencinta ilmu:

a. Bertanya dan diam (as-Sual was Shumtu)

b. Mendengarkan (al-Istima')

c. Mengingat-ingat/mengenang (at-Tafakkur)

d. Mengamalkan ilmu (al-Amalu fil ilmi)

e. Mencari kejujuran dari diri sendiri (Tahabus Shidqy min Nafsihi)

f. Menjahukan kekaguman atas prestasi yang dicapai (tarkul ijaab bima yuhsin uhu).

Mereka memandang "Ilmu itu dapat mendatangkan keilmuam bagi pemiliknya yang sebelumnya hina, dapat mendatangknan 
kedudukan tinggi yang semula rendah, dapat mendatangkan kekayaan yang sebelumnya miskin, dapat menjadi kuat yang sebelumnya miskin, dapat menjadi kuat yang sebelumnya lemah, dapat merubah menjadi pemurah yang sebelumnya bakhil.

7. Pemahaman mereka mengenai perkembangan jiwa condong kepada teori Tabularasa. Kata mereka ketahuilah bahwa pikiran jiwa sebelum mendapatkan ilmu atau paham adalah bagaikan selembar kertas putih bersih yang belum tertulis apapun padanya. Bila sudah tertulis sesuatau, benar atau salah maka ruang jiwa itu sudah berisi dan menolak untuk ditulisi sesuatu yang lain dan sukar untuk menghilangkan dan menghapusnya.

8. Paham mereka tentang proses belajar. Semua ma'rifaj (pengetahuan) merupakam perolehan (muktabasah) bukan bawaan (fitriyah). Dalil di atas demikian adalah firman Allah:

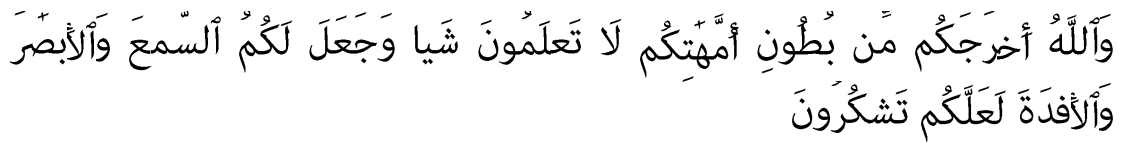

Dan Allah mengeluarkan kamu dari perut ibumu dalam keadaan tidak mengetahui sesuatupun, dan Dia memberi kamu pendengaran, penglihatan dan hati, agar kamu bersyukur. (QS. An-Nahal, 78).

Menurut Ikwanus Shafa pengetahuan umum dapat diperoleh dengan tiga cara yaitu: Indra, akal untuk berpikir murni dan inisiasi. (Nata, 1997: 182).

9. Metode pembiasaan menurut ikhwanus Shafa Jika semua ma'rifah (ilmu) itu adalah perolehan, lalu bagaiman memperpolehnya? Caranya menurut Ikhwanus Shafa ialah: Pembiasaan, mencontoh/menirukan dan berguru. Pembiasaan itu dilakukan dengan berkelanjutan disertai kesadaran. Adat kebiasaan yang dilakukan berkelanjutan akan membentuk budi pekerti yang dicita-citakan seperti halnya belajar dan membahas tentang ilmu dengan berkelanjutan akan memperkuat intelektualitas serta memantapkan ilmu itu sendiri.

Dari beberapa pokok pemikiran Ikhwanus Shafa tentang pendidikan di atas, jelas bahwa pemikiran mereka memiliki 
relevansi dengan dunia pendidikan sekarang ini baik itu dalam perumusan karakteristik peserta didik, kriteria guru yang baik, dan sebagainya. Terutama tujuan, metode, dan kurikulumnya yang sangat relevan dengan pendidikan di era gobal ini. Dapat dilihat masih sesuainya pemikiran Ikhwanus Shafa dengan beberapa rumusan sistem pendidikan di indonesia.

\section{Catatan Akhir}

Ikhwan al-ashafa adalah perkumpulan para mujtahidin dalam bidang filsafat yang banyak memfokuskan perhatiannya pada bidang dakwah dan pendidikan. Perkumpulan ini lahir pada abad ke-10 M di kota Basrah, pada masa pemerintahan al-Mansyur, khalifah kedua Bani Abbas. Dari Basrah, Ikhwan al-Shafa terus menyebar dan berkembang ke berbagai daerah seperti Iran dan Kuwait.

Menurut Ikhwan as-Shafa, aktivitas pendidikan dimulai sejak sebelum kelahiran. Sebab, kondisi diri bayi dan perkembangannya sudah dipengaruhi oleh keadaan kehamilan dan kesehatan sang ibu yang hamil. Dengan demikian, perhatian pendidikan harus sudah diberikan sejak masa janin dalam rahim.

Ikwan as-Shafa menempatakan pendidik (guru) pada posisi strategis dan inti dalam kegiatan pendidikan. Mereka mempersyaratkan kecerdasan, kedewasaan, kelurusan moral, ketulusan hati, kejernihan pikir, etos keilmuan dan tidak fanatik buta apda diri pendidik. Ikwan as-Shafa menganggap bahwa mendidik sama dengan menjalankan fungsi "bapak." kedua, karena pendidikan atau guru merupakan bapak bagi dirimu, pemelihara pertumbuhan dan perkembangan jiwa, sebagaimana halnya kedua orang tuamu adalah pembentuk rupa fisik-biologismu, maka guru adalah pembentuk rupa mental-rohaniah. 


\section{Daftar Pustaka}

Abdullah, Amin, Dkk. 2004. Pendidikan Islam dan Tantangan Globalisasi Buah Pikiran Seputar: Filsafat, Politik, Ekonomi, Sosial, dan Budaya. Yogyakarta: Ar-Ruzz Media.

Maragustam. 2014. Filsafat Pendidikan Islam : Menuju Pembentukan Karakter Menghadapi Arus Global, Yogyakarta: Kurnia Kalam Semesta.

Nasution, Hasyimsyah. 2002. Filsafat Islam. Jakarta: Gaya Media Pratama.

Nata, Abuddin. 2003. Manajemen Pendidikan, Mengatasi kelemahan Pendidikan Islam di Indonesia. Jakarta: Prenada Media.

Nata, Abudin. 1997. Filsafat Pendidikan Isalm. Jakarta: Logos Wacana Ilmu.

Nizar, Samsul.2002. Filsafat Pendidikan Islam Pendekatan Historis, Teoritis dan Praktis, Jakarta: Ciputat Pers.

Ridla, Muhammad Jawad. 2002. Tiga Aliran Utama Teori Pendidikan: Perspektif Sosiologis-Filosofis, Yogyakarta: Tiara WacanaYogya. 